\title{
NUMERICAL AND EXPERIMENTAL INVESTIGATION OF THE EFFECT OF HYDROSTATIC PRESSURE ON THE RESIDUAL STRESS IN BOILER-TUBE WELDS
}

\author{
NUMERIČNA IN EKSPERIMENTALNA PREISKAVA VPLIVA \\ HIDROSTATIČNEGA TLAKA NA ZAOSTALE NAPETOSTI V \\ ZVARU NA KOTLOVSKI CEVI
}

\author{
Daryoush Danyali, Eslam Ranjbarnodeh \\ Amir Kabir of University of Technology, Department of Mining and Metallurgical Engineering, Tehran, Iran \\ islam_ranjbar@yahoo.com, islam_ranjbar@aut.ac.ir \\ Prejem rokopisa - received: 2015-08-13; sprejem za objavo - accepted for publication: 2015-10-09
}

doi:10.17222/mit.2015.255

A tube to tube-sheet weld joint is a critical section in many boilers. Leakage and failure are two common problems that can occur with this type of joint. The tensile residual stresses associated with welding can play a major role in these problems. In the present study, the Finite-Element Method is used to predict the residual stresses in a tube to tube-sheet weld and the effect of hydrostatic pressure on the residual stresses' redistribution. Investigations were performed by numerical analyses and experimental methods. The joint included a circumferential fillet weld in one pass using a gas tungsten arc welding process. The thermomechanical behavior of the joint is simulated with a two-dimensional axisymmetric model and a subroutine developed in ANSYS software. The thermography method is used for the thermal verification and the hole-drilling strain gauge under post-weld heat treatment is used for the mechanical analysis verification. The numerical and experimental results showed that applied hydrostatic pressure can reduce, by about $58 \%$, the axial residual stress.

Keywords: hydrostatic test, residual stress, boiler tubes, tube-sheet, finite element method (FEM)

Kritični področji v kotlih sta zvarjen spoj cevi in cevne predelne stene. V tej vrsti spoja sta glavna problema, ki se pojavljata, puščanje in porušitev. Zaostale natezne napetosti povezane $\mathrm{z}$ varjenjem so glavni dejavnik pri teh problemih. V študiji je bila uporabljena metoda končnih elementov za napovedovanje zaostalih napetosti v zvarih cevi in cevne predelne stene in vpliv hidrostatičnega tlaka na razporeditev zaostale napetosti. Raziskave so bile izvedene $\mathrm{z}$ numerično analizo in $\mathrm{z}$ eksperimentalnimi metodami. Spoj je vključeval obodni zvar izdelan v obloku z volframovo elektrodo in zaščito s plinom. Termomehansko obnašanje spoja je bilo simulirano z uporabo dvodimenzijskega osnosimetričnega modela in programa razvitega z ANSYS programsko opremo. Termografska metoda je uporabljena za preverjanje toplote in pri toplotni obdelavi zvarov je bila uporabljena metoda $\mathrm{z}$ merilnimi lističi na izvrtini za preverjanje mehanske analize. Numerični in eksperimentalni rezultati so pokazali, da uporabljen hidrostatični tlak, lahko za $58 \%$ zmanjša osne zaostale napetosti.

Ključne besede: hidrostatični preizkus, zaostala napetost, kotlovske cevi, cevna predelna stena, metoda končnih elementov (FEM)

\section{INTRODUCTION}

Boilers are a very important part of many industries, such as power generation, food, hospitals, and hotels. Boilers are the most troublesome components of electrical power generation plants. It costs the US utility industry over $\$ 5$ billion per year in unscheduled shutdowns, repairs and power replacements. ${ }^{1}$ In general, the safety and structural integrity of a boiler are of paramount importance. Welding is common method in the boiler-manufacturing process and the process of welding has a direct influence on the integrity of the components and their thermal and mechanical behaviors during service. Micro-cracking in tube to tube-sheet welds, in both the radial and circumferential directions, is commonplace. ${ }^{2}$

The nature of failures in the vicinity of the tube to tube-sheet interfaces is particularly difficult to determine because of the large temperature gradients as well as the relatively high pressures. Due to the high temperatures introduced during welding and the subsequent cooling of the welded metal, welding can produce undesirable residual stresses and deformations. Radial cracking is more likely to occur, but circumferential cracking also occurs and results from the thermal cycling, which is exacerbated by a high residual stress. ${ }^{3}$ The thermal stress, mechanical stress and welding residual stress of tube to tube-sheet has received a lot of attention in recent years.

B. Yildrim and H. F. Nied ${ }^{4}$ investigated the residual stress and distortion in boiler-tube panels with welded overlay cladding. X. Qingren ${ }^{5}$ reported that residual stress in the circumferential weld in pipes is reduced when hydrostatic pressure is increased. To the best of the knowledge of the author, a very limited number of FEM models have been proposed for predicting the residual stresses in a tube to tube-sheet weld and the effect of hydrostatic pressure test on the residual stresses in this type of joint. The present study uses a two dimensional 


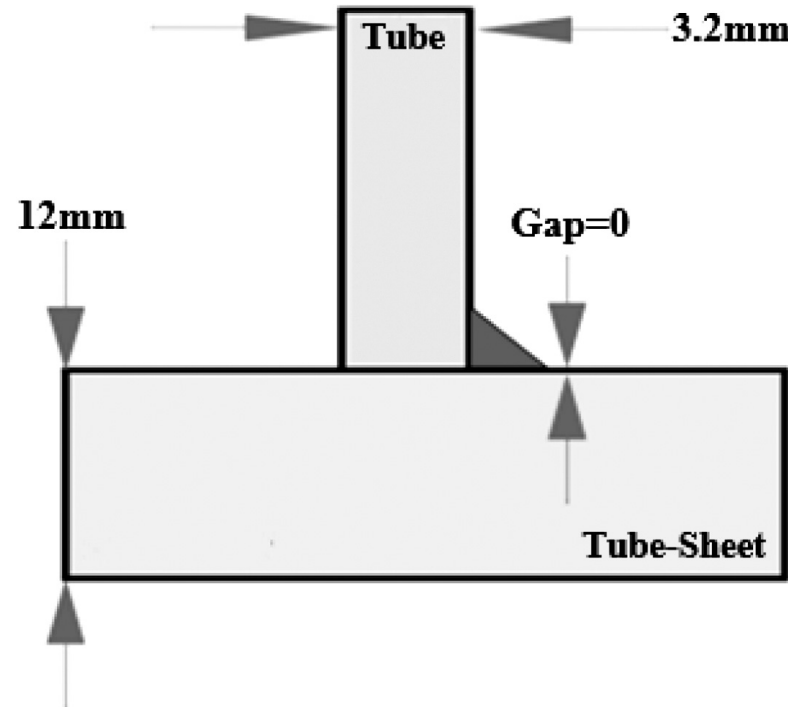

Figure 1: Schematic of geometrical model for verification Slika 1: Shematski prikaz geometrijskega modela za preverjanje

axisymmetric FEM model for the calculation and distribution of the residual stresses in a tube to tube-sheet joint. The Thermography Method is used for the thermal verification and the hole-drilling strain gauge under post-weld heat treatment is used for the mechanical analysis verification and then the effect of hydrostatic pressure on the redistribution residual stresses is investigated by numerical analyses and experimental methods.

\section{FEM AND VERIFICATION PROCEDURES}

\subsection{Welding verification procedures}

To verify the results of the FEM method, an experimental test with the same geometry, material and welding parameters was produced, as shown in Figure 1.

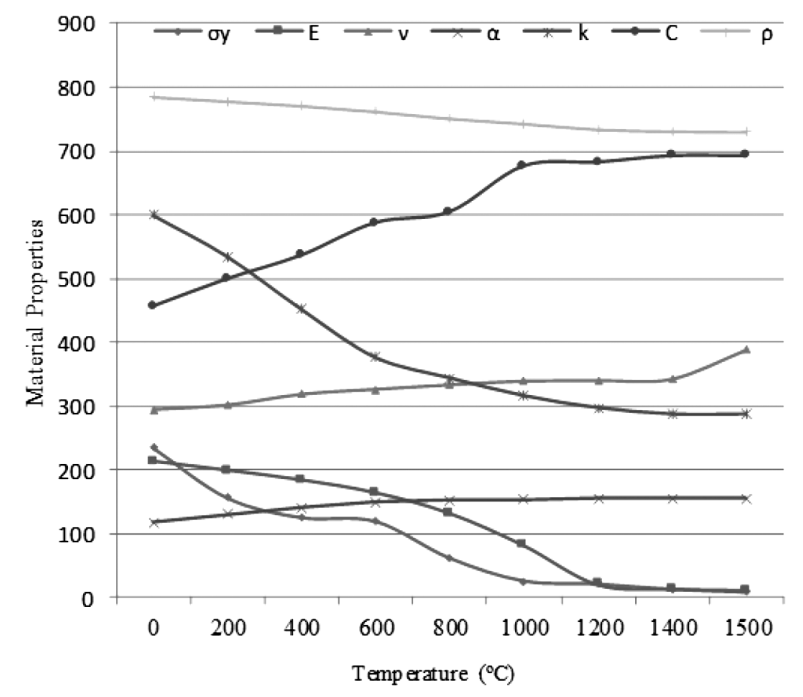

Figure 2: Thermo-physical and mechanical properties Slika 2: Termofizikalne in mehanske lastnosti

\subsection{Material properties}

The base metal of the tube was steel St35.8 and tube-sheet was steel $17 \mathrm{Mn} 4$. The chemical compositions are listed in Table $\mathbf{1 .}$

Table 1: Chemical composition in mass fractions $(w / \%)$

Tabela 1: Kemijska sestava v masnih odstotkih $(w / \%)$

\begin{tabular}{|c|c|c|c|c|c|c|}
\hline Composition & $\mathrm{C}$ & $\mathrm{Si}$ & $\mathrm{Mn}$ & $\mathrm{P}$ & $\mathrm{S}$ & $\mathrm{Cr}$ \\
\hline St35.8 & 0.17 & 0.35 & 0.60 & 0.03 & 0.03 & - \\
\hline $17 \mathrm{Mn} 4$ & 0.20 & 0.20 & 0.120 & 0.03 & 0.025 & 0.30 \\
\hline
\end{tabular}

For the thermal and mechanical analyses, the relationship between the thermo-physical and the thermomechanical properties of the materials with temperature is incorporated, as shown in Figure 2.

The welding parameters used were exactly as same as the boiler-repair parameters. The dimensions of the welded parts are presented in Table 2.

Table 2: The dimensions of the pieces used

Tabela 2: Dimenzije uporabljenih kosov

\begin{tabular}{|c|c|c|c|c|}
\hline Material & $\begin{array}{c}\text { Diameter } \\
(\mathrm{mm})\end{array}$ & $\begin{array}{c}\text { Width } \\
(\mathrm{mm})\end{array}$ & $\begin{array}{c}\text { Width } \\
(\mathrm{mm})\end{array}$ & $\begin{array}{c}\text { Thickness } \\
(\mathrm{mm})\end{array}$ \\
\hline Tube & 51.8 & - & 200 & 3.2 \\
\hline Tube-sheet & - & 80 & 80 & 12 \\
\hline
\end{tabular}

\subsection{Thermal verification procedure}

To verify the thermal model, thermography was used. In this study, the welding temperature was monitored with a model $\mathrm{T} 8$ thermography camera. It helps to record the temperature during the welding and after the weld cooling.

\subsection{Mechanical model verification procedure}

To verify the weld profile obtained using the FEM method, a section was prepared for macroscopic examination of the welded samples. The section was prepared, polished and etched in a solution with $50 \mathrm{~mL}$ of $37 \%$ hydrochloric acid and $50 \mathrm{ml}$ of distilled water for 30 minutes. After the etching period it was examined macroscopically.

\subsection{Residual stress verification procedure}

The hole-drilling strain gauge under post-weld heat treatment is based on the principle that if a hole in a piece is created, stresses around the hole and the hole will be released. When this amount increases, the mobility of the hole will increase. The strain and thus the amount of residual stresses can be calculated by determining the displacement of the hole. This procedure is based on Tait's research. ${ }^{3}$

The amounts of axial residual stresses were produced by the drilling under post-weld heat treatment technique. 


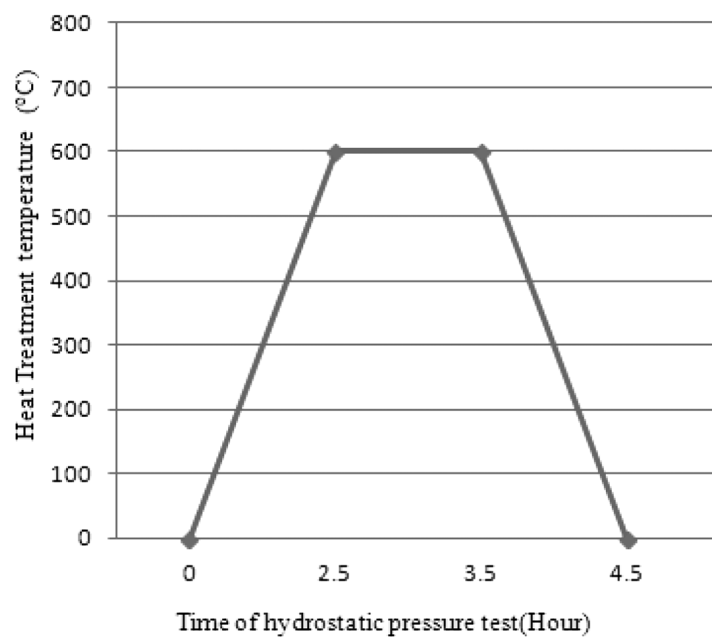

Figure 3: Heat-treatment cycle

Slika 3: Potek toplotne obdelave

The samples were drilled using a TOSKURIM drilling machine.

The high-speed steel drill was $2 \mathrm{~mm}$ in diameter, known as the drill chuck. The rotation speed was $2743 \mathrm{~min}^{-1}$ and the forward speed of the drill was 0.05

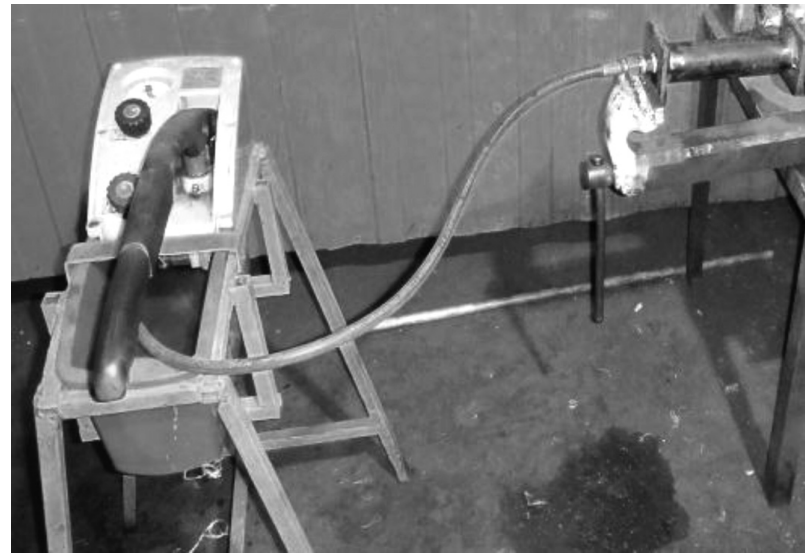

Figure 4: Hydrostatic test setup

Slika 4: Sestav za hidrostatični preizkus

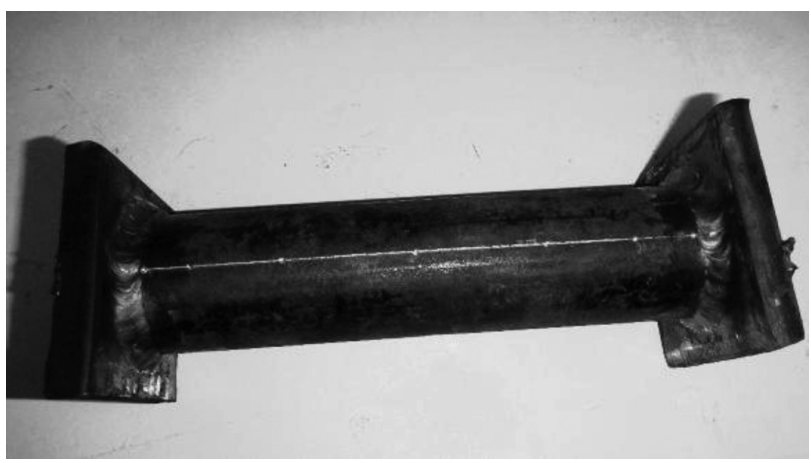

Figure 5: The sample drilled for axial residual stress measurement and hydrostatic tests

Slika 5: Zvrtan vzorec za merjenje aksialnih zaostalih napetosti in hidrostatični preizkus $\mathrm{mm} / \mathrm{min}$. After drilling, the distances between the holes were measured and recorded with a MITUTOYO micrometer type with an accuracy of up to $0.02 \mathrm{~mm}$. After measuring the distance between the holes, the samples were heat treated according to the guidelines for heat treatment. ${ }^{5}$

The applied heating rate was $220^{\circ} \mathrm{C} / \mathrm{h}$. The welded parts were held at $620^{\circ} \mathrm{C}$ for an hour and then they were allowed to cool with a cooling rate of about $275^{\circ} \mathrm{C} / \mathrm{h}$, cooled in furnace to $300{ }^{\circ} \mathrm{C}$ and after that in air. Figure 3 shows the applied heat-treatment cycle for the welded parts in this study. ${ }^{6}$

After that the samples were cooled, the distances between the holes were measured and recorded again in the same manner using the same micrometer. The residual stresses in the specimens are released by drilling the specimens, and the axial strain, $e_{x}$, and transverse released strain, $e_{y}$, are measured. Using the measured strains, the axial residual stress, $\sigma_{x}$, can be obtained from Equation (1): ${ }^{7}$

$$
\sigma_{x}=\left[-E /\left(1-v^{2}\right)\right]\left(e_{x}+v e_{y}\right)
$$

where $E$ is Young's modulus and $v$ is Poisson's ratio.

\subsection{Hydrostatic test verification procedure}

Before applying hydrostatic pressure, the distances between holes were measured and recorded again. The drilling apparatus and procedure were the same as used in the calculation of the residual stresses. Figure 4 shows a hydrostatic test setup and Figure 5 shows the sample drilled to investigate the behavior of residual stresses after the hydrostatic pressure.

To create the real conditions, like hydrostatic test conditions, the welded part was restrained between the fixed jaws of a clamp. The fittings for the pressure-testing machine were installed and water with a temperature of about $15{ }^{\circ} \mathrm{C}$ was injected into the welded part. When the air bubbles exit completely, a pressure equal to 1.5 times the boiler's design pressure was applied to the welded part. ${ }^{6}$ Due to the design the pressure of the investigated boiler in this study was $0.4 \mathrm{MPa}$, while the

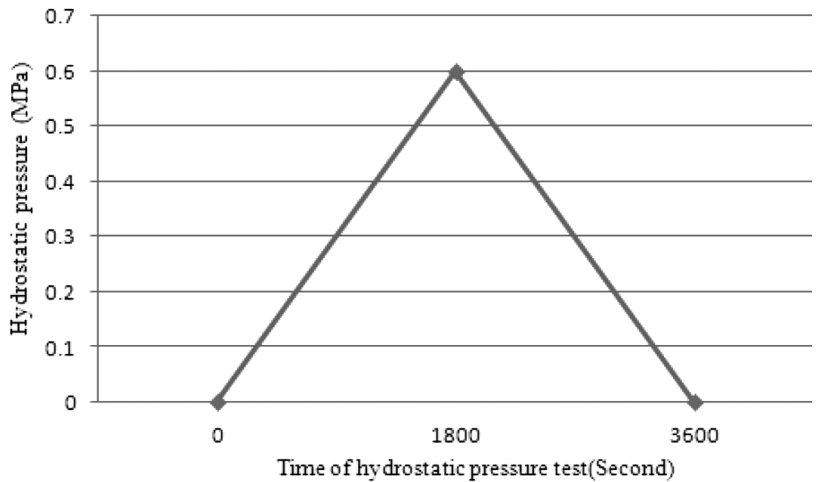

Figure 6: Applied hydrostatic pressure as a function of time Slika 6: Uporabljen hidrostatični tlak v odvisnosti od časa 
applied hydrostatic pressure to the welded part was about $0.6 \mathrm{MPa}$.

Figure 6 shows the applied hydrostatic pressure as a function of time. After $1800 \mathrm{~s}$, the hydrostatic pressure was removed. After the completion of the hydrostatic testing procedure, the distances between the drilling locations were measured and recorded with the same micrometer.

\subsection{FEM meshed model}

The FEM model of the welding process is performed on the St35.8 steel tube with an outer diameter of $51 \mathrm{~mm}$ and a wall thickness of $3 \mathrm{~mm}$, and $17 \mathrm{Mn} 4$ steel tubesheet with a wall thickness of $12 \mathrm{~mm}$ using a single pass. There was no gap between the tube and tube-sheet. The welding process used was gas tungsten arc welding. For a more convenient calculation, a part of the tube-sheet was selected for the FEM analysis. Although the real welding is a three-dimensional procedure, it is often considered sufficient to represent a circumferential weld with a two-dimensional axisymmetric FEM model. ${ }^{7}$ The two-dimensional axisymmetric FEM model is much faster and easier to perform..$^{8} 9$ Therefore, the methodology described here is based on a two-dimensional axisymmetric model.

The meshed model is shown in Figure 7. For the meshing, plane55 and Surf151 elements were used for thermal analysis and the plane82 element was used for the mechanical analysis. In total, 346 nodes and 303 elements were generated. The welding of the tube to tube-sheet was performed with a single pass weld. In the weld adjacent, the meshing was very fine due to the high thermal gradient of this region during the welding process.

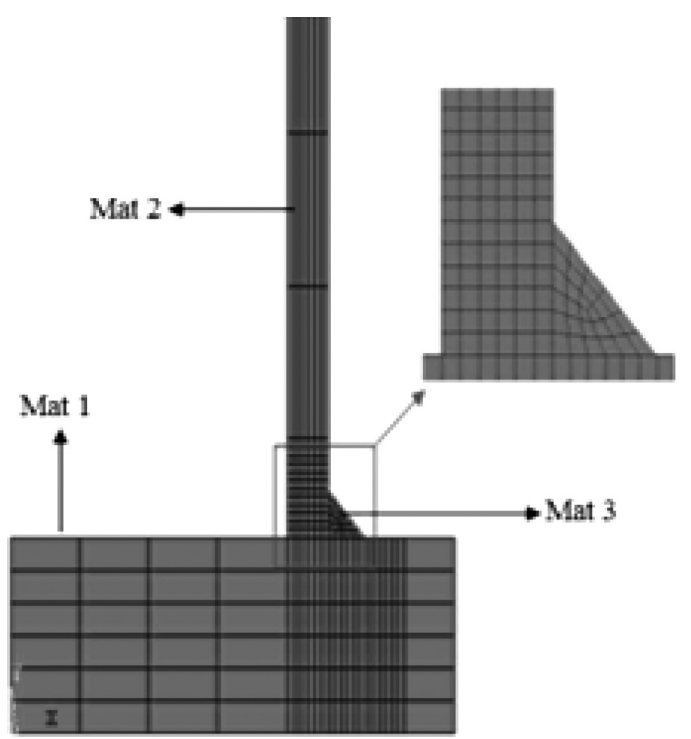

Figure 7: FEM meshed model

Slika 7: Model mreže za FEM

\subsection{Thermal analysis}

The heat equation is a parabolic partial differential equation that describes the distribution of heat (or variations in temperature) in a given region over the time and is generally describes by Fourier's relation, Equation $(2){ }^{6}$

$\rho c_{\mathrm{p}}\left(\frac{\partial}{\partial t}\right)=\frac{\partial}{\partial x}\left[K_{x} \frac{\mathrm{d} T}{\mathrm{~d} x}\right]+\frac{\partial}{\partial y}\left[K_{y} \frac{\mathrm{d} T}{\mathrm{~d} y}\right]+\frac{\partial}{\partial z}\left[K_{z} \frac{\mathrm{d} T}{\mathrm{~d} z}\right]+Q$

where $\rho$ is the density $\left(\mathrm{kg} / \mathrm{m}^{3}\right), C_{\mathrm{p}}$ is the specific heat capacity $(\mathrm{J} / \mathrm{kg} \mathrm{K}), K(\mathrm{~W} / \mathrm{m} \mathrm{K})$ is the thermal conductivity, $Q$ is the heat input (W), and $T$ is the temperature (K).

The Gaussian function is calculated by following Equation (3):6,10

$$
q(r)=\left(\frac{3 Q}{\pi r_{0}^{2}}\right) \exp \left[-3\left(\frac{r}{r_{0}^{2}}\right)\right]
$$

where $q(r)$ is the heat flux $\left(\mathrm{W} / \mathrm{m}^{2}\right), r_{0}$ is the radius of the welding heat source that is estimated to be about one half of the Gaussian curve width, $r$ is the distance from the middle point of the heat source to the center, and $Q$ is the heat input (W) that is calculated using Equation $(4): 6$

$$
Q=V \cdot I \cdot \eta
$$

where $V$ is the welding voltage, $I$ is the welding current, and ç is the welding efficiency. In this paper $V, I, \eta$ and $r_{0}$ were $10 \mathrm{~V}, 120 \mathrm{~A}, 0.85$ and $10 \mathrm{~mm}$, respectively. The filler metal, welding speed and gas flow rate were ER70S-6, $5 \mathrm{~cm} / \mathrm{min}$ and $15 \mathrm{~L} / \mathrm{min}$, respectively.

The fluid flow in the welding pool increases the heat-transfer rate, which has an important effect on the temperature field in the welding process. The effect of fluid flow on the weld pool temperature for the whole temperature field is considered by the heat-transfer coefficient, $h$. In this study, as in a previous study, $h=15$

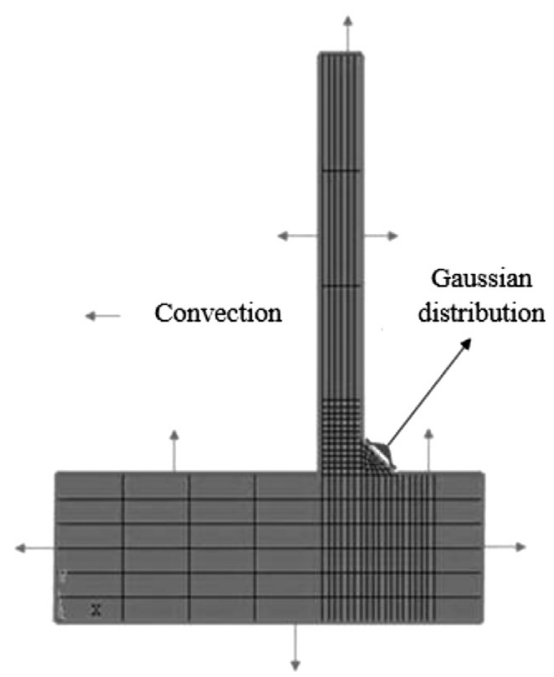

Figure 8: The applied thermal boundary conditions Slika 8: Uporabljeni toplotni robni pogoji 


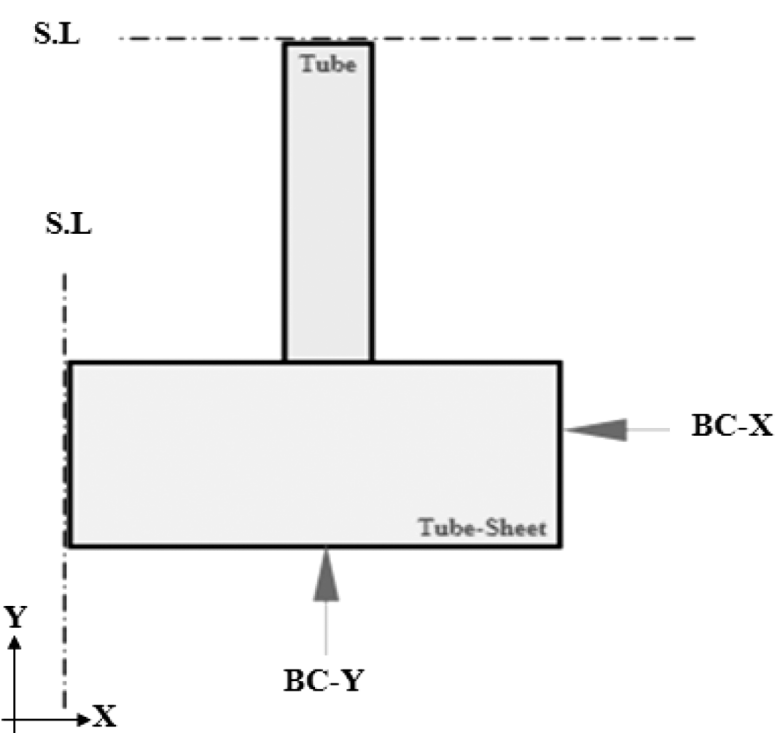

Figure 9: The mechanical boundary conditions Slika 9: Mehanski robni pogoji

$\mathrm{W} / \mathrm{K} \mathrm{m}^{2} .{ }^{11}$ Due to the small thickness of the parts, preheating before welding is not done and the initial temperature of the welded parts was assumed to be $27{ }^{\circ} \mathrm{C}$. Figure 8 shows the applied thermal boundary conditions.

\subsection{Mechanical analysis}

The residual stress was calculated by using the temperature distribution obtained from the thermal analysis as input data. The material properties relevant to the residual stress are the Young's modulus, the yield strength, the Poisson's ratio, and the coefficient of thermal expansion. The total strain can be decomposed into three components, as in Equation (5): ${ }^{11}$

$$
\varepsilon^{\text {thotal }}=\varepsilon^{\mathrm{e}}+\varepsilon^{\mathrm{p}}+\varepsilon^{\mathrm{th}}
$$

where $\varepsilon^{\mathrm{e}}, \varepsilon^{\mathrm{p}}$, and $\varepsilon^{\mathrm{t}}$ are the elastic strain, plastic strain and thermal strain, respectively. The elastic strain was modeled using the isotropic Hooke's law with a temperature-dependent Young's modulus and Poisson's ratio. During the mechanical analysis, boundary conditions were applied to prevent the rigid-body motion. Figure 9 shows the applied mechanical boundary conditions. Because of the tube-sheet rigidity, $\mathrm{BC}-\mathrm{X}$ is constrained in the $\mathrm{X}$-direction and $\mathrm{BC}-\mathrm{Y}$ is constrained in the Y-direction. The S.L lines are axisymmetric lines.

\section{RESULTS AND DISCUSSION}

\subsection{Thermal results}

The thermal contour recorded by the experimental method is shown in Figure $\mathbf{1 0}$ and the thermal results recorded by experiment and the FEM are shown in Figure 11. The weld-pool peak temperatures of the FEM model and the experiments are $1900{ }^{\circ} \mathrm{C}$ and $1716{ }^{\circ} \mathrm{C}$,
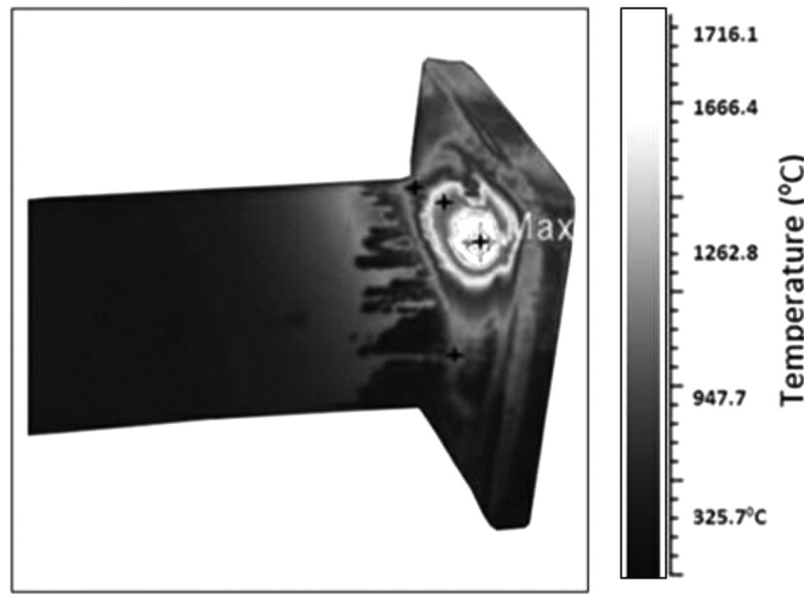

Figure 10: Contours of the thermal history

Slika 10: Plastnice termične zgodovine

respectively. This $10 \%$ difference shows the good agreement between the experimental results and the FEM model. This difference could be due to changes in thermo-physical properties of the materials as a function of the temperature, the difference in the thermal conductivity. In the same way, Majzobi and colleagues conducted a study in which a thermography technique was used to record the thermal history. ${ }^{12}$ The thermal history

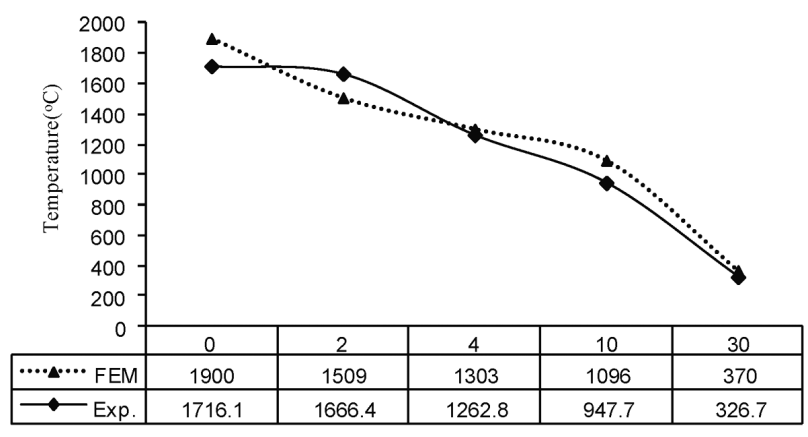

Figure 11: Curves of the thermal history

Slika 11: Krivulji toplotne zgodovine

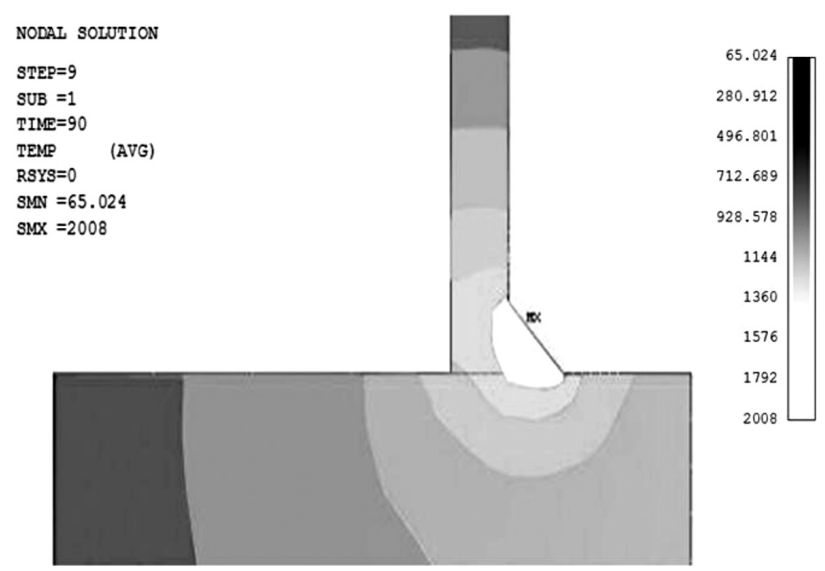

Figure 12: Temperature contours for the FEM model during welding Slika 12: Razporeditev temperature pri FEM modelu med varjenjem 


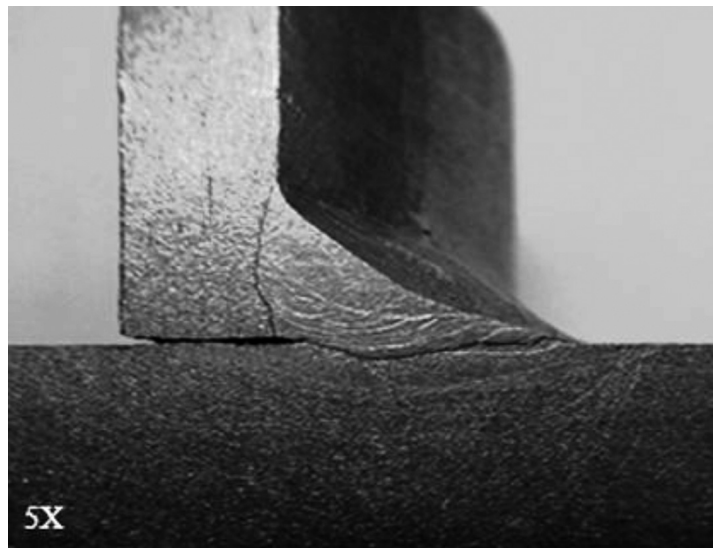

Figure 13: The weld profile using the experimental method Slika 13: Profil zvara pri preizkusu

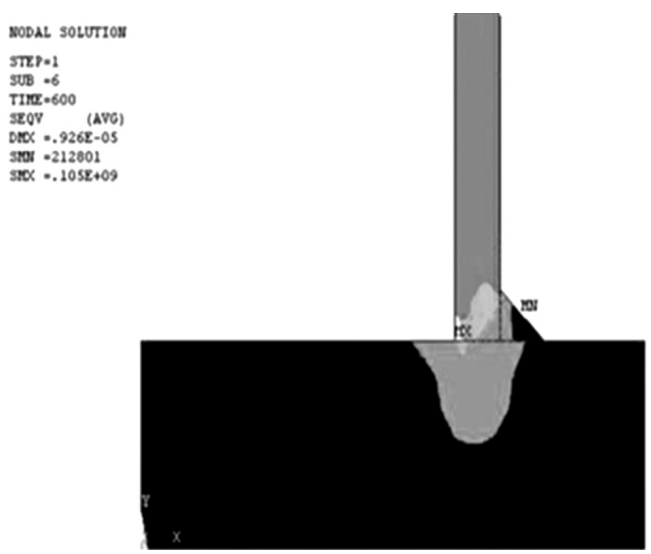

Figure 14: Residual stresses results in axial direction using the FEM method, before the hydrostatic test

Slika 14: Zaostale napetosti v osni smeri po FEM metodi, pred hidrostatičnim preizkusom

of the contours recorded by the other researches also shows a difference of about $11 \%$, which confirms the results of the present study.

The weld profile that is created with the FEM is shown in Figure 12. The peak of the weld's penetration is $1.06 \mathrm{~mm}$ into the tube. The weld profile that is created using the experimental method is shown in Figure 13. The peak of the weld penetration is $1.2 \mathrm{~mm}$ into the tube.

Comparing these two sets of results shows that greatest difference in the amount of weld penetration into the tube-sheet is about $12 \%$. The results are proved to be in a logical agreement for the FE method and experimental results.

\subsection{Mechanical behavior under hydrostatic effect}

The residual stresses contour in the axial direction is shown in Figure 14. The axial residual stress calculated by the FEM and experimental methods is shown in Figure 15. The peak axial residual stress of $105 \mathrm{MPa}$ is located in the weld root zone. The peak axial residual stress calculated by the experimental method was 85.94

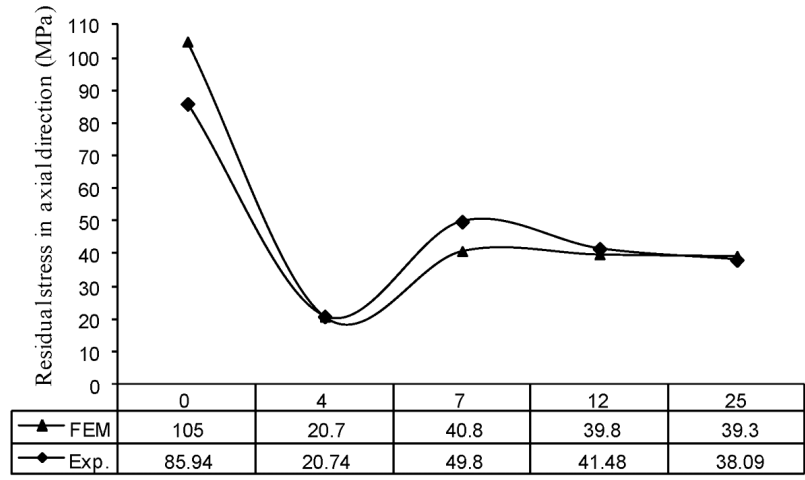

Axial Distan from tube-sheet (mm)

Figure 15: Residual stresses results in axial direction using the FEM method, before the hydrostatic test

Slika 15: Zaostale napetosti v smeri osi, po FEM metodi, pred hidrostatičnim preizkusom

MPa. The axial residual stresses first decrease from the peak value, and then start to increase. All the axial residual stresses decrease along the weld and the outer surface of the tube. The axial residual stress values are
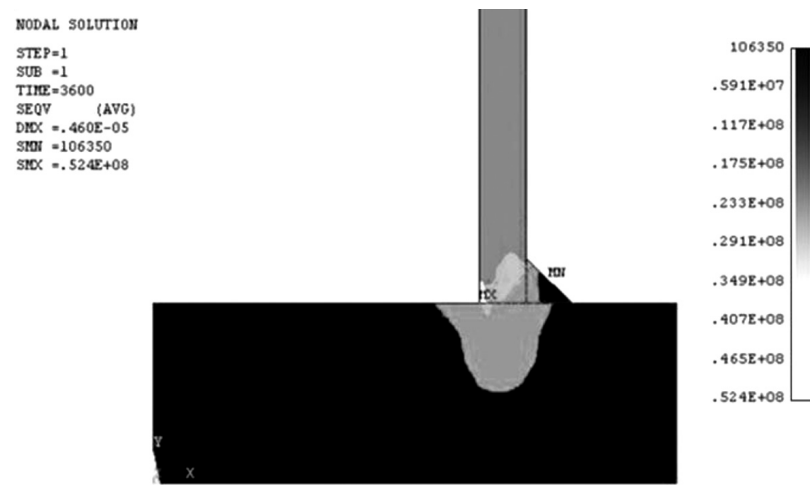

Figure 16: Residual stresses in axial direction using the FEM and experimental methods, after the hydrostatic test

Slika 16: Zaostale napetosti $\mathrm{v}$ smeri osi po FEM in eksperimentalni metodi, po hidrostatičnem preizkusu

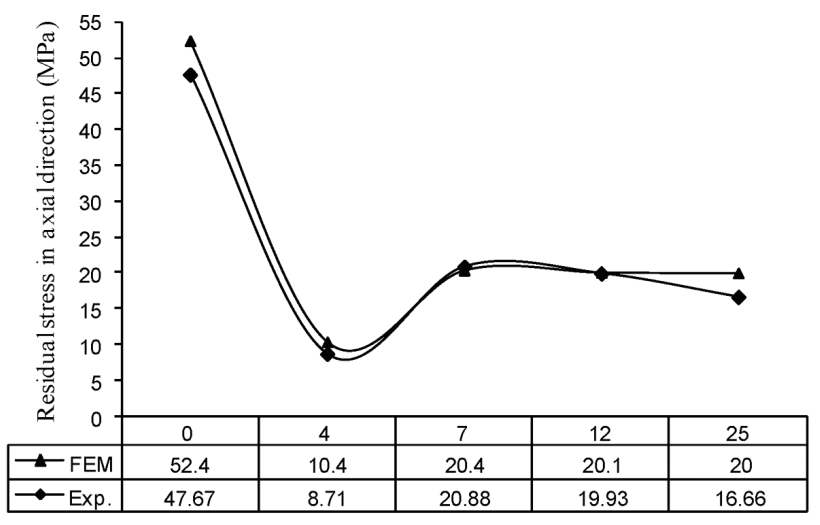

Axial Distan from tube-sheet $(\mathrm{mm})$

Figure 17: Residual stresses in axial direction using the FEM and experimental methods, after the hydrostatic test

Slika 17: Zaostale napetosti v osni smeri po FEM in po eksperimentalni metodi, po hidrostatičnem preizkusu 


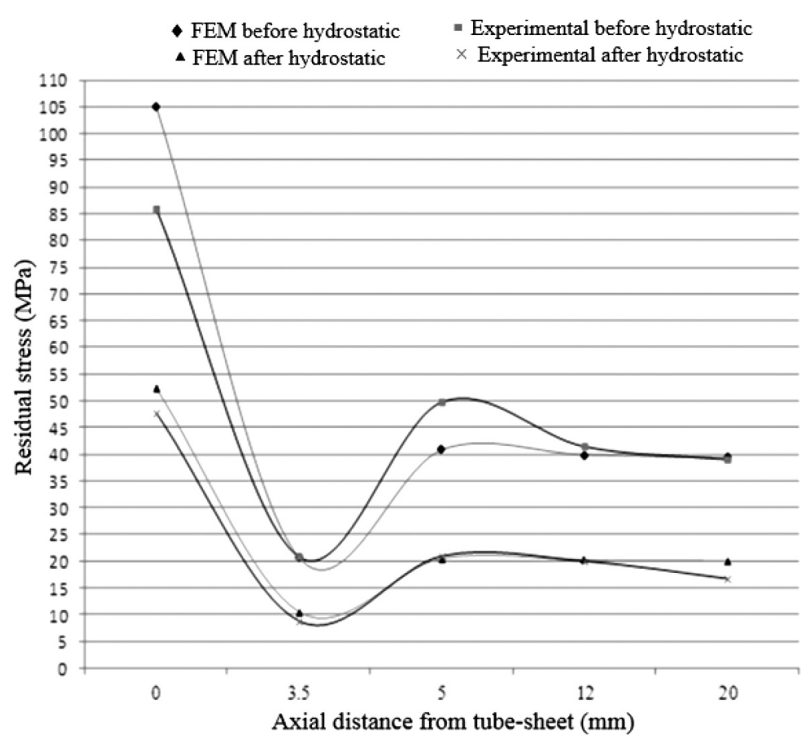

Figure 18: Residual stresses in the axial direction using the FEM and experimental methods, before and after the hydrostatic test

Slika 18: Zaostale napetosti v osni smeri po FEM in po eksperimentalni metodi, pred in po hidrostatičnem preizkusu

reasonable, compared to Sattari-Far's research results. ${ }^{13,14}$ The maximum difference between the two methods is $18 \%$ and the lowest is $2 \%$. As compared to Tait's results ${ }^{2}$, the findings of the present study are acceptable. The peak axial tensile residual stress is 105 $\mathrm{MPa}$ in the root of the joint, which caused the initiation and growth of fatigue cracks under cyclic loading in this boiler joint.

In order to investigate the effect of the hydrostatic test on the residual stress in the axial direction in a boiler-tube weld, hydrostatic pressure is applied using the FEM and experimental methods. Figure 16 shows the curve of the residual stress results in the axial direction using the FEM and experimental methods, before the hydrostatic test. It is clear that the hydrostatic pressure affects the residual stress in the axial direction, as shown in Figure 17. The maximum difference between the two methods is about $9 \%$. The results of the FE method show a peak in the residual stress in the axial direction after the application of the hydrostatic pressure is $52.4 \mathrm{MPa}$. The results of the experimental method show that the peak residual stresses in the axial direction after the application of hydrostatic pressure is $47.7 \mathrm{MPa}$.

The residual stresses in the axial direction calculated by the FEM method in the weld root are shown in Figure 18. The residual stresses in the axial direction calculated by the FEM method in weld root show that the application of a hydrostatic test pressure after the welding process can reduce the tensile residual stresses in the axial direction from $105 \mathrm{MPa}$ to of $52.4 \mathrm{MPa}$, i.e., by approximately $51 \%$. The results of the residual stresses in the axial direction calculated using the FEM method in the weld toe shows that hydrostatic pressure can reduce the tensile residual stresses in the axial direction from 40.8 MPa to 20.4 MPa, i.e., a reduction of about $50 \%$. The residual stresses in the axial direction calculated using the experimental method in the weld shows that applying a hydrostatic test pressure after the welding process can reduce the tensile residual stresses in the axial direction from 20.74 MPa to 8.71 MPa. This means a reduction of about $58 \%$. The reason for this reduction can be sought in the accumulation of the hydrostatic pressure and the previous residual stresses that were caused by plastic deformation. In the plastically deformed region, the total stresses exceeded the yield strength and partial relaxation of the residual stresses can be occurred.

\section{CONCLUSIONS}

This study predicted the axial residual stresses and their behavior under hydrostatic pressure using the FEM and experimental methods. The results of this study can be summarized as follows:

1. The root of tube to tube-sheet joint and the weld toe were two critical points with the maximum axial tensile residual stress.

2. Applying a hydrostatic pressure after the welding process could reduce the axial tensile residual stresses in the weld by about $58 \%$.

3. Applying a hydrostatic pressure after the welding process could reduce the axial tensile residual stresses in the root of tube to tube-sheet joint by about $50 \%$.

4. Applying hydrostatic pressure after the welding process could reduce the axial tensile residual stresses in the weld toe by about $51 \%$.

5. It was easier and cheaper to calculate the residual stresses in the design of a complex geometry in connection with a corner joint with a very low thickness using the technique of strain measurement accuracy of the hole under the heat treatment.

6. The results of the present study could be generalized for other critical boiler joints, such as the shell to furnace joint and the furnaces to tube-sheet joint.

7. The results of the present study could be generalized to other high-pressure equipment including heat exchangers, hot-water boilers, hot-oil boilers and any other equipment that has a tube to tube-sheet joint.

\section{REFERENCES}

${ }^{1} \mathrm{X}$. Shugen, W. Weiqiang, Numerical investigation on weld residual stresses in tube to tube sheet joint of a heat exchanger, Int. J. Pres. Ves. Pip., 101 (2013), 37-44, doi:10.1016/j.ijpvp.2012.10.004

${ }^{2}$ R. Tait, J. Press, Investigation An experimental study of the residual stresses, and their alleviation, in tube to tube-sheet welds of industrial boilers, Engineering Failure Analysis, 8 (2001), 15-27, doi:10.1016/j.engfailanal.2013.04.01

${ }^{3}$ K. Abouswa, F. Elshawesh, A. Abuargoub, Stress corrosion cracking (caustic embrittlement) of super heater tubes, Desalination, 222 (2008), 682-688, doi:10.1016/j.desal.2007.02.073 


\section{DANYALI, E. RANJBARNODEH: NUMERICAL AND EXPERIMENTAL INVESTIGATION OF THE EFFECT ...}

${ }^{4}$ B. Yildrim, H. F. Nied, Residual Stress and Distortion in Boiler Tube Panels with Welded Overlay Cladding, Journal of Pressure Vessel Technology - Transactions of ASME, 126 (2004), 426-431, doi:10.2320/matertrans.126.426

${ }^{5}$ X. Qingren, F. Yaorong, H. Chun-Yong, The measurement and control of residual Stress in spiral submerged arc welded pipe, Proceedings of 4th International pipeline conference, Calgary, 2002, $615-622$

${ }^{6}$ British Standards Institute, BS2790, Design and manufacturing of shell boilers of welded construction, 1992, 80-100

${ }^{7}$ C. Lee, K. Chang, Numerical investigation of residual stresses in Strength mismatched dissimilar steel butt welds, J. Strain Analysis, 43 (2008), 55-66, doi:10.1243/03093247JSA313

${ }^{8}$ T. Soanes, W. Bell, A. Vibert, Optimizing residual stresses at a repair in a steam header to tube plate weld, Int. J. Pres. Ves. Pip., 82 (2005), 311-318, doi:10.1016/j.ijpvp.2004.08.009

${ }^{9}$ D. Deng, H. Murakawa, Numerical simulation of temperature field and residual stress in multi-pass welds in stainless steel pipe and comparison with experimental measurements, Comp. Mater. Sci., 37 (2006), 269-277, doi:10.1016/j.commatsci.2005.07.007
${ }^{10} \mathrm{X}$. Shugen, Z. Yanling, Using FEM to determine the thermo mechanical stress in tube to tube-sheet joint for the SCC failure analysis, Engineering Failure Analysis, 34 (2013), 24-34, doi:10.1016/j.engfailanal.2013.07.01

${ }^{11}$ T. Tso-Liang, F. Chin-Ping, C. Peng-Hsiang, Y. Wei-Chun, Analysis of residual stresses and distortion in T-joint fillet welds, Int. J. Pres.Ves. Pip., 78 (2001), 523-538, doi:10.1016/j.ijpvp.2000.07.008

${ }^{12}$ J. Otegui, P. Fazzini, Failure analysis of tube-tubesheet welds in cracked gas heat exchangers, Engineering Failure Analysis, 11 (2004), 903-913, doi:10.1016/j.engfailanal.2004.01.003

${ }^{13}$ I. Sattari-Far, Y. Javadi, Influences of welding sequence on welding distortion in pipes, Int. J. Pres. Ves. Pip., 85 (2008), 265-274, doi:10.1016/j.engfailanal.2007.02.004

${ }^{14}$ I. Sattari-Far, M. Farahani, Effect of the weld groove shape and pass number on residual stresses in butt-welded pipes, Int. J. Pres. Ves. Pip., 86 (2009), 769-777, doi:10.1016/j.ijpvp.2009.07.007 